\title{
IdeAs
}

Idées d'Amériques

1| 2011

Intégrations dans les Amériques

\section{Macroeconomic Synchronization and Policy Coordination After Regional Economic Integration in the Americas}

El impacto de la integración económica regional en la sincronización macroeconómica y la coordinación de políticas

L'impact de l'intégration économique régionale sur la synchronisation macroéconomique et la coordination des politiques

\section{Helen Chang}

\section{OpenEdition}

Journals

Édition électronique

URL : https://journals.openedition.org/ideas/60

DOI : 10.4000/ideas.60

ISSN : $1950-570$

Éditeur

Institut des Amériques

Référence électronique

Helen Chang, "Macroeconomic Synchronization and Policy Coordination After Regional Economic Integration in the Americas », IdeAs [En ligne], 1 | 2011, mis en ligne le 31 août 2011, consulté le 19 octobre 2022. URL : http://journals.openedition.org/ideas/60 ; DOI : https://doi.org/10.4000/ideas.60

Ce document a été généré automatiquement le 19 octobre 2022.

Creative Commons - Attribution - Pas d'Utilisation Commerciale - Pas de Modification 4.0 International - CC BY-NC-ND 4.0

https://creativecommons.org/licenses/by-nc-nd/4.0/ 


\title{
Macroeconomic Synchronization and Policy Coordination After Regional Economic Integration in the Americas
}

\author{
El impacto de la integración económica regional en la sincronización \\ macroeconómica y la coordinación de políticas \\ L'impact de l'intégration économique régionale sur la synchronisation \\ macroéconomique et la coordination des politiques
}

Helen Chang

While much of the research and debate on assessing the consequences of the North American Free Trade Agreement (NAFTA) and Dominican Republic-Central American Free Trade Agreement (CAFTA-DR) is concentrated on levels of foreign direct investment (FDI), trade deficits and diversion, changes in factor markets, and gross domestic product (GDP) growth, the effects of NAFTA and CAFTA-DR on the macroeconomic synchronization and policy coordination of member countries is still contested and less systemically known. Although NAFTA and the CAFTA-DR each established a free trade area (FTA) that eliminated trade barriers for member countries, they had no explicit terms on the management of macroeconomic policies for member states. However, with increased economic integration resulting from these free trade agreements, the macroeconomic cycles of member countries may become more closely synchronized. Symmetry in business cycles is important first because it is critical in determining the utility and efficacy of macroeconomic policy coordination. Specifically, high business cycle synchronization between partner countries indicates that policy coordination would be beneficial for member countries, and asymmetry would imply the need for independent fiscal and monetary policies ${ }^{1}$

2 Second, macroeconomic synchronization is important for developing country partners in a FTA, because synchronous effects with high-income partners may increase the 
financial stability of developing member states by reducing their macroeconomic volatility. While there is prior scholarship on macroeconomic synchronization and policy coordination, much of it focuses on the European Union ${ }^{2}$, which largely consists of a group of deeply integrated high-income industrial states, the work on NAFTA tends to focus on only one of the important relationships described here, and similar research on CAFTA-DR is limited due its more recent implementation. To clarify these two key relationships under NAFTA and CAFTA-DR, I examine the degree of macroeconomic synchronization and policy coordination between NAFTA countries and between CAFTA-DR states and discuss the economic and political implications of current levels of macroeconomic synchronization and policy coordination for partner countries.

3 Section 1 begins with a presentation of the theoretical and empirical literature on macroeconomic synchronization and economic integration and then considers macroeconomic synchronization after NAFTA and CAFTA-DR. I find some indication of increasing synchronization between partner countries post-NAFTA. There is also some preliminary evidence that CAFTA-DR economies also show some convergence postCAFTA-DR. Then in Section 2, I look at the relationship between macroeconomic synchronization and volatility between NAFTA states and between CAFTA-DR countries. Overall, macroeconomic volatility has decreased for NAFTA and CAFTA-DR members. Specifically, Canada is less susceptible to spillover effects from the United States (US) and Mexico. In contrast, the Mexican economy is much more susceptible to spillover effects from the US, which increases financial instability. CAFTA-DR states also face negative spillover effects due to slowdowns in US growth. This indicates that synchronization is not always beneficial and can be costly in an economic downturn. Finally in Section 3, I present the theoretical conditions under which policy coordination is desirable and then analyze levels of policy coordination after NAFTA and CAFTA-DR. I find that there is not much policy coordination in the post-NAFTA and post-CAFTA-DR.

\section{Macroeconomic Synchronization after Economic Integration}

The literature on business cycles and trade has established a link between trade intensity and business cycle synchronization. Frankel and Rose discovered this regularity by looking at 20 industrialized economies and found that countries that trade more also have higher business cycle symmetry (Frankel, Rose 1998 : 1009-1025). This finding is supported by later studies of European state (Fidrmuc 2004: 1-12) and by work that includes a cross-national sample of both industrial and developing countries(Calderon, Chong, Stein 2007). However, this relationship is: (1) stronger between industrial countries, weaker in industrial-developing pairs, and weakest in developing country pairs (Ibid.) and (2) weaker between states with more interindustry trade and thus, asymmetries in production structures ${ }^{3}$ and stronger between states with more intra-industry trade and therefore, similarities in production structures (Imbs 2004: 723-734; Calderon, Chong, Stein, op. cit.). These mixed results means that while trade intensity increases with a FTA, synchronization does not automatically result between all member states. 
5 Rather, business cycle convergence also depends on the degree of economic specialization and financial integration between member countries as well as labor market integration (Inklaar, Jong-A-Pin, de Haan 2005). In fact, synchronization could decrease if a free trade agreement encourages specialization between countries (Lederman, Maloney, Servén, 2005: 81). Conversely, as financial shocks more easily cross borders with financial integration, financial integration could also likely lead to an increase in macroeconomic synchronization, as capital mobility makes domestic interest rates and financial asset prices more sensitive to international conditions (Ibid.:82). Then considering labor, work on OECD countries found that labor market heterogeneity reduces business cycle synchronization (Fonseca, Patureau, Sopraseuth, 2010: 867). While free trade agreements typically do not liberalize labor markets, trade integration can indirectly lead to more labor market integration through competition in the production market (Martinoia 2009: 5). As a result, "when capital mobility is combined with trade liberalization, and when production becomes more integrated across national borders, the employment and earnings prospects for workers in different countries become increasingly interdependent," (Blecker 2003: 6) which can also contribute to some synchronization.

6 Taken together, we should expect regional integration to contribute to business cycle synchronization between industrial high-income partners in a FTA. Considering trade integration first, industrial high-income partners will tend to have similar production structures with higher levels of intra-industry trade (IIT) (Grubel, Lloyd 1975; Caves 1981: 203-223), including both vertical and also horizontal intra-industry trade, in which traded products are of similar quality but have different attributes (Krugman 1981 : 959-973). High levels of IIT indicate product integration between markets and so may also point to some labor market integration. In terms of financial integration, which occurs when financial assets face a single set of rules and the equalization of returns on those financial assets, high-income industrial countries are more financially integrated than developing countries as determined by capital restriction and openness measures (International Monetary Fund 2001: 146-152). This indicates that high-income industrial pairs may be more financially integrated than industrial-developing and developing pairs. Preferential trade agreements can also directly affect levels of FDI, with the inclusion of provisions for investment liberalization as well as indirectly affect FDI through trade liberalization. So FDI flows can be used to show financial integration. In general, regional integration has a positive effect on FDI (Kreinin, Plummer 2008: 497-454). This is because the factors that are influenced by trade liberalization, GDP growth and market size significantly affect the flow of FDI (Worth 1998: 82). Thus, states with higher growth and larger market sizes will likely have more FDI and the extent to which a trade agreement affects those factors will determine how much a FTA affects FDI (Ibid). Specifically, Feils and Rahman's study of NAFTA found that NAFTA has had a significant positive effect on FDI flows for the United States and Canada but not Mexico (Feils, Rahman 2008: 147-163). So this FDI approach also supports the implication that high-income industrial pairs are more financially integrated.

7 For industrial-developing partners, we should expect some but not as much business cycle convergence in comparison to industrial high-income pairs. Industrialdeveloping pairs do participate in vertical IIT. This vertical trade results from production sharing and so it may also indicate some labor market integration. In addition, since specialization in vertical trade occurs mainly within an industry, 
specialization does not necessarily lead to asymmetric production structures and industry specific shocks. As a result, vertical IIT can lead to increased macroeconomic synchronization. However, economic integration between industrial nations and developing countries is widely believed to generate more inter-industry trade than IIT (Clark, $2007: 493$ ). Therefore, industrial-developing partners will tend to have more asymmetric production structures than industrial high-income pairs. Regarding financial integration, the pace of investment liberalization for developing countries is slower than industrial countries based on capital restriction and openness measures (International Monetary Fund op. cit). This indicates that industrial-developing pairs may be less financially integrated than high-income industrial pairs. In addition, while regional integration does have positive effect on FDI (Kreinin, Plummer op. cit.), taking from the NAFTA experience, this effect may not be very strong for developing countries (Feils, Rahman op. cit.). However, several empirical studies have found evidence of cointegrated Mexican, Canadian, and US equity markets after the implementation of NAFTA (Gilmore, McManus 2004: 137-150; Aggarwal, Kyaw, 2005: 393-406; ChukwuogorNdu and Kasibhatla 2007: 37-53). Thus, there is evidence of financial integration in a FTA with asymmetrical partners but this effect is weaker for the developing state.

8 Finally, developing pairs in a FTA should be the least synchronized. Even though IIT exists among developing countries, the amount of IIT decreases as GNP per capita drops for any state, and also decreases along with greater differences in GNP per capita between states (Havrylyshyn, Civan 1985). This also means that labor market integration is less likely. Additionally, as economic integration creates more interindustry trade between industrial nations and developing countries, developing pairs will each be more specialized since their individual production and trade will likely be focused on the larger markets of high-income industrial partners rather than another developing state in the FTA. So developing country partners will also have the most asymmetrical production structures in comparison to industrial pairs and industrialdeveloping partners. Since the level of investment liberalization is lower for developing states, we should also expect financial integration between developing states to be weak although there may be an overall effect of financial integration if trade and capital flows of both states are oriented toward a high-income industrial partner.

However, it must be noted that even though scholars have found a positive link between trade and macroeconomic synchronization, it is difficult to exactly quantify a FTA's effect on macroeconomic synchronization. This is because we do not know precisely how much trade policy would be liberalized without a FTA, given already increasing trade in the time periods considered here. Similarly, we do not know specifically how much volatility would be moderated and how much synchronicity would grow without a FTA, given existing economic trends of tempering economic volatility and increasing macroeconomic synchronicity in the time periods examined in this study.

10 Moreover, concluding a simple direct causation between a FTA and macroeconomic synchronization is not possible in view of other known determinants of macroeconomic synchronization. These other determinants scholars have found and explored are: trade intensity, trade specialization, economic specialization, policy coordination, and financial integration (Böwer, Guillemineau 2006). While some scholars contest the magnitude of these effects, the literature reviewed in this section 
has shown the effect of regional integration on trade intensity, trade specialization, economic specialization, and financial integration.

\subsection{Macroeconomic Synchronization after NAFTA}

11 NAFTA was implemented in January 1994 by Mexico, a developing state; Canada, highincome state; and the United States, another high-income state ${ }^{4}$. Since the implementation of NAFTA, trade flows have generally increased between partner countries (Kose, Rebucci 2005: 79; Kose, Meredith, Towe 2004: 13-14). Scholars have largely agreed that NAFTA has had an effect on trade intensity although they do differ on the significance of this phenomenon (Congressional Budget Office 2003). This is because trade was also influenced by Mexico's unilateral liberalization after joining the General Agreement on Tariffs and trade in 1986, US economic expansion in the 1990s, and the Mexican Peso devaluation in 1995 (Villarreal 2003).

Considering types of trade, the following survey of empirical research on trade finds support for prior work described in Section 1 in which high-income industrial pairs in a FTA take part in more IIT than industrial-developing and developing partners, who participate in more inter-industry trade. Between 1993-2007 for the US-Mexico pair, the average Grubel-Lloyd (GL) index values, which measures IIT, were largely static and the trade weighted GL index values decreased over time (Clark 2010: 3). Furthermore, measurements of IIT indexes and marginal IIT indexes confirm that post-NAFTA trade between the U.S. and Mexico has remained mostly inter-industry and trade growth has been predominately due to inter-industry trade (Shelburne 2001: 215-234). Examining Mexico's inter-industry trade share, it increased from 59.7\% in 1993 to $61.9 \%$ in 2007 (Ekanayake, Veeramacheneni Moslares, 2009: 34). In comparison, trade between Canada and the United States is significantly intra-industry in nature as calculated in 2000 (Fontagné, Freudenberg, Gaulier 2005: 22), and this IIT has increased as measured by marginal IIT indexes from 1980-1998 (Bruilhart, Thorpe 2001). Looking at interindustry trade share, it decreased from 52.6\% in 1993 to 50.2\% in 2007 for Canada (Ekanayake, Veeramacheneni, Moslares op. cit.). Similarly, the trade after NAFTA in just agricultural products between Canada and Mexico and the US and Mexico has been found to be largely inter-industry trade while the US-Canada pair is largely characterized by IIT (Qasmi, Fausti 2001: 255-271).

Considering financial integration and the terms of NAFTA, investors from within NAFTA are generally guaranteed equal treatment with domestic investors for most manufacturing sectors and a few service sectors, as well as transparent regulations (Feils, Rahman, op. cit.:148). In general, FDI flows between NAFTA partners have also expanded after the agreement (Kose, Meredith, Towe, op. cit.: 16-17). There has also been increasing co-integration of Mexican, Canadian, and US equity markets after the implementation of NAFTA (Gilmore, McManus op. cit.: 137-150; Aggarwal, Kyaw op. cit.: 393-406; Chukwuogor-Ndu, Kasibhatla op. cit.: 37-53). However, as mentioned earlier, Feils and Rahman's more recent work on NAFTA found that NAFTA has had a substantial positive effect on FDI flows for the United States and Canada but not on Mexico (Feils, Rahman, op. cit.: 147-163). These patterns indicate that while there has been some overall financial integration in the three NAFTA states, the effect has been weaker for Mexico. 
Turning to labor, while NAFTA did not formally address labor market issues ${ }^{5}$, shifts in trade and production can still affect labor market integration. However, studies on the impact of NAFTA on aggregate employment have found little or no significant effect on NAFTA members (Burfisher, Robinson, Thierfelder 2001: 130). Using wage criteria, Robertson also discovers little evidence of a significant effect from NAFTA on labor market integration between the US and Mexico (Robertson 2005: 425-448). So as the theoretical and empirical literature has indicated, we should expect higher business cycle convergence between Canada and the US ${ }^{6}$ and lower business cycle convergence between Mexico and the US and Mexico and Canada.

Previous research in international business cycle synchronization has typically relied on two measures of macroeconomic synchronization: (1) various measures of correlations of bilateral output over time and (2) the proportion of output variation that is due to common factors (International Monetary Fund 2007: 121-160). I use output correlation coefficients since I am interested in looking at the contemporaneous synchronization in annual output variables between two states ${ }^{7}$.

Table 1 below presents Pearson correlation coefficients of output from World Bank data using annual data (World Bank, 2011). I used three measures of output: the natural log of exports of goods and services, the natural log of value added industrial output, and gross domestic product (GDP) growth as an annual percent. Furthermore to detrend the data, it was first differenced. To help look at the potential impact of an FTA, I separated the data into equal time periods before and after the implementation of NAFTA, in this case 15 years and for the entire period between 1978-2009.

Table 1

\begin{tabular}{|c|c|c|c|}
\hline \multicolumn{4}{|c|}{ Output Correlation Coefficients } \\
\hline & $\begin{array}{l}\text { Natural Log of Exports of Goods } \\
\text { and Services (constant } 2000 \text { US\$) }\end{array}$ & $\begin{array}{l}\text { Natural Log of Value Added } \\
\text { Industry (constant } 2000 \text { US\$) }\end{array}$ & $\begin{array}{l}\text { GDP Growth } \\
\text { (annual \%) }\end{array}$ \\
\hline $\begin{array}{l}\text { US-Mexico } \\
1978-1993\end{array}$ & -0.188 & $0.958^{* * *}$ & 0.247 \\
\hline $\begin{array}{l}\text { US-Mexico } \\
\text { 1994-2009 }\end{array}$ & $0.810^{* * *}$ & $0.549^{* *}$ & $0.767^{* * *}$ \\
\hline $\begin{array}{l}\text { US-Mexico } \\
1978-2009\end{array}$ & $0.408^{* *}$ & $0.941^{* * *}$ & $0.395^{* *}$ \\
\hline $\begin{array}{l}\text { Canada-Mexico } \\
1978-1993\end{array}$ & -0.234 & $0.962^{* * *}$ & 0.436 \\
\hline $\begin{array}{l}\text { Canada-Mexico } \\
\text { 1994-2009 }\end{array}$ & $0.884^{* * *}$ & $0.613^{* *}$ & $0.509^{*}$ \\
\hline $\begin{array}{l}\text { Canada-Mexico } \\
\text { 1978-2009 }\end{array}$ & $0.528^{* * *}$ & $0.948^{* * *}$ & $0.445^{* *}$ \\
\hline $\begin{array}{l}\text { US-Canada } \\
1978-1993\end{array}$ & 0.270 & $0.996^{* * *}$ & $0.861^{* * *}$ \\
\hline
\end{tabular}




\begin{tabular}{|l|l|l|l|}
\hline $\begin{array}{l}\text { US-Canada } \\
1994-2009\end{array}$ & $0.677^{* * *}$ & $0.874^{* * *}$ & $0.815^{* * *}$ \\
\hline $\begin{array}{l}\text { US-Canada } \\
1978-2009\end{array}$ & $0.541^{* * *}$ & $0.991^{* * *}$ & $0.845^{* * *}$ \\
\hline \multicolumn{2}{|l}{ Significance levels: ${ }^{*}=\mathrm{p}<0.1,{ }^{* *}=\mathrm{p}<0.05,{ }^{* * *}=\mathrm{p}<0.01$} & \\
\hline
\end{tabular}

17 For exports, the correlation coefficients indicate greater synchronization between member states after NAFTA with the greatest shift between high-income partners and Mexico. Considering GDP growth, there seems to be increased co-movement between Mexico and the US and not much change between the other member states. Looking at value added industrial output, both high-income pairs and Mexico have a lower correlation coefficient after NAFTA. This is an indication that industrial structures are changing between the high-income partners and Mexico during this time period. It must be noted that changes in industrial structure of developed economies, particularly in the US began in the 1960's with the shift away from manufacturing and agriculture to services (Fuchs 1968). However, research on the impact of NAFTA on key labor-intensive industries, namely the automotive, electronics, and textiles and apparel industries, has found increased production sharing through the expansion of the maquiladora industry in the post-NAFTA period for the US and Mexico ${ }^{8}$. Overall, following theoretical and empirical predictions, between the US and Canada, there are generally higher levels of output correlations. The correlation coefficients are overall less strong in the Mexican case, just as one would expect.

In terms of sector output correlations, which point toward asymmetrical or symmetrical production structures between states, Table 2 below illustrates bilateral sector Pearson's $r$ for the natural log of value added agriculture, the natural log of value added manufacturing, and the natural log of value added services sectors from annual World Bank data (World Bank op. cit.). Value added data in each sector was used as a more accurate measure of sector output than gross figures. Then to detrend the data, it was first differenced. I separated the results into equal time periods before and after the implementation of NAFTA, in this case 11 years and for the entire period between 1982-2005.

Table 2

\begin{tabular}{|c|c|c|c|}
\hline \multicolumn{4}{|c|}{ Sector Correlation Coefficients } \\
\hline & $\begin{array}{l}\text { Natural Log of Value } \\
\text { Added } \\
\text { (constant } 2000 \text { US } \$ \text { ) }\end{array}$ & $\begin{array}{l}\text { Natural Log of Value Added } \\
\text { Manufacturing (current US } \\
\$ \text { ) }\end{array}$ & $\begin{array}{l}\text { Natural Log of Value } \\
\text { Added } \\
\text { (constant } 2000 \text { US } \$ \text { ) }\end{array}$ \\
\hline $\begin{array}{l}\text { US-Mexico } \\
1982-1993\end{array}$ & 0.287 & 0.440 & -0.128 \\
\hline $\begin{array}{l}\text { US-Mexico } \\
1994-2005\end{array}$ & 0.036 & -0.097 & $0.770^{* * *}$ \\
\hline
\end{tabular}




\begin{tabular}{|l|l|l|l|}
\hline $\begin{array}{l}\text { US-Mexico } \\
1982-2005\end{array}$ & 0.204 & 0.208 & 0.216 \\
\hline $\begin{array}{l}\text { Canada- } \\
\text { Mexico } \\
1982-1993\end{array}$ & 0.050 & 0.050 & -0.165 \\
\hline $\begin{array}{l}\text { Canada- } \\
\text { Mexico } \\
1994-2005\end{array}$ & 0.235 & 0.235 & 0.409 \\
\hline $\begin{array}{l}\text { Canada- } \\
\text { Mexico } \\
1982-2005\end{array}$ & 0.204 & 0.119 & 0.128 \\
\hline $\begin{array}{l}\text { US-Canada } \\
1982-1993\end{array}$ & -0.004 & $0.809^{* * *}$ & $0.717^{* * *}$ \\
\hline $\begin{array}{l}\text { US-Canada } \\
1994-2005\end{array}$ & 0.418 & $0.645^{* *}$ & 0.436 \\
\hline $\begin{array}{l}\text { US-Canada } \\
1982-2005\end{array}$ & 0.204 & $0.696^{* * *}$ & $0.635^{* * *}$ \\
\hline Significance levels: ${ }^{*}=\mathrm{p}<0.1, * * \mathrm{p}<0.05,{ }^{* * *}=\mathrm{p}<0.01$ & \\
\hline
\end{tabular}

In the agricultural industry, there are lower correlations in the NAFTA period between the Mexico-US pair and the Canada-Mexico pair and higher between the US-Canada pair but all the correlations are weak in this sector, signifying low symmetry. Although on the whole agricultural trade between NAFTA members has grown in the post-NAFTA period, this expansion has not been uniform. For example, US agricultural exports to Mexico doubled from 1993-2003 and Canada became the largest importer of US agricultural goods while value added by Mexican agriculture dropped from $\$ 32$ billion in 1993 to \$25 billion in 2003 (Hufbauer, Schott, 2005: 287-289). Considering the manufacturing and the service sectors, there are high correlations for the US-Canada pair but they decreased post-NAFTA. This may generally indicate more symmetrical production structures but also some adjustments in the post-NAFTA period. For the USMexico pair and the Canada-Mexico pair in manufacturing and the service sectors, the correlations are largely weak. As we expect from the literature, overall weak correlations for the US-Mexico and Canada-Mexico pairs suggest asymmetrical production structures and generally higher correlations indicate more symmetrical production structures for the US and Canada.

In the post-NAFTA period, there are signs that macroeconomic synchronization is increasing between partner countries. However, by looking at output and sector correlations, this synchronization is greater between the US and Canada in comparison to the US and Mexico and Canada and Mexico. These results support prior research that has found increasing co-movement between the NAFTA partners. For instance, Torres and Vela have found that the Mexican business cycle has synchronized with the United States following regional integration (Torres, Vela 2003: 319-342). In addition, Cuevas, 
Messmacher, and Werner discover the synchronization of Mexican macroeconomic cycles with Canadian and American cycles and the increase in co-movement between Mexican and American sectoral business cycles (Cuevas, Messmacher, Werner 2003). Finally, Kose, Meredith, and Towe find there has been an increase in business cycle synchronization between Mexico and the United States and Canada using the common factor approach (Kose, Meredith, Towe op. cit,: 20-21).

\subsection{Macroeconomic Synchronization after CAFTA-DR}

Developing partner states of CAFTA-DR currently are the Dominican Republic (March 2007), Costa Rica (January 2009), El Salvador (March 2006), Guatemala (July 2006), Nicaragua (April 2006), and Honduras (April 2006) ${ }^{9}$. The US is the only high-income partner and began its participation in March 2006 with El Salvador. As a group in 2004, CAFTA-DR states were the $12^{\text {th }}$ largest market for US exports and the $15^{\text {th }}$ largest supplier of imports (Clark op. cit.:505). However, the individual CAFTA-DR states are relatively small economies to the United States and the extent of trade linkages differ among the various CAFTA-DR states. The Dominican Republic, which has the largest trade share with the US among the CAFTA-DR states, found its exports to the US largely stagnate after the CAFTA-DR agreement but generally increase with other CAFTA-DR members, although one must take into account the global economic crisis that unfolded in late 2008 (Molina, Bussolo, Iacovone 2010). Overall, the United States has increased its exports to the CAFTA-DR states since CAFTA-DR by 14.4\% in 2006 (Hornbeck 2008a: 6), 16\% in 2007 (Hornbeck 2008b: 7), and 12.45\% in 2008 (Hornbeck 2009: 8) but not surprisingly down 21.3\% in 2009 (Hornbeck 2010: 9). But taking from Mexico's NAFTA experience, trade intensity between the CAFTA-DR states should increase over time in the long term, although trade volumes between individual CAFTA-DR states are much lower than for NAFTA countries (Kose, Rebucci op. cit.: 83). Thus in comparison to NAFTA states, the post-CAFTA shift may be more modest. Moving on to the composition of trade after CAFTA-DR, studies have found that although the US is the largest trading partner for CAFTA-DR countries by far, IIT as measured by GL indexes are very low between the US and CAFTA-DR states in the pre-CAFTA-DR period from 1992-2004 (Clark op. cit.: 493-496). So production structures are already more asymmetrical between the US and CAFTA-DR states even before CAFTA-DR implementation. Looking to the record of the post-NAFTA period, we should expect increasing inter-industry trade and some growth in vertical IIT between industrial-developing pairs in the postCAFTA period. Again following the NAFTA experience, we should not anticipate much labor market integration under CAFTA-DR. Finally, regarding financial linkages between CAFTA-DR states, they were already increasing in the mid-1990s before the CAFTA-DR agreement because of the increase in foreign ownership of banks, high dollarization, and the rise of capital flows (Swiston, 2010: 8-9). As a result, we should see stronger financial integration in the CAFTA-DR period. So in terms of macroeconomic synchronization, we should expect some but not much convergence between the US and the developing states of CAFTA-DR, especially in the short-term.

For data purposes, I chose El Salvador, Guatemala, and Honduras to represent the developing states, since they have been members since 2006, other CAFTA-DR members joined more recently, and the available annual World Bank data (World Bank op. cit.) would not be sufficient for any kind of analysis ${ }^{10}$. Since the data covers just four years after CAFTA-DR, the analysis only reflects short-term adjustments and fluctuations and 
no long-term inference can be made. Correlation coefficients given in Table 3 are Pearson's $\mathbf{r}^{11}$.

Table 3

\begin{tabular}{|c|c|c|c|}
\hline \multicolumn{4}{|c|}{ Output Correlation Coefficients } \\
\hline & $\begin{array}{l}\text { Natural Log of Exports of Goods } \\
\text { and Services (constant } 2000 \\
\text { US\$) }\end{array}$ & $\begin{array}{l}\text { Natural Log of Value Added } \\
\text { Industry (constant } 2000 \\
\text { US\$) }\end{array}$ & $\begin{array}{l}\text { GDP Growth } \\
\text { (annual \%) }\end{array}$ \\
\hline $\begin{array}{l}\text { US-El Salvador } \\
2002-2005\end{array}$ & -0.313 & -0.833 & -0.881 \\
\hline $\begin{array}{l}\text { US-El Salvador } \\
2006-2009\end{array}$ & 0.892 & 0.857 & 0.972 \\
\hline $\begin{array}{ll}\text { US-El Salvador } \\
2002-2009\end{array}$ & 0.709 & 0.470 & 0.726 \\
\hline $\begin{array}{l}\text { US-Guatemala } \\
2002-2005\end{array}$ & 0.499 & -0.260 & 0.152 \\
\hline $\begin{array}{l}\text { US-Guatemala } \\
2006-2009\end{array}$ & 0.896 & $0.991^{* * *}$ & $0.950^{* *}$ \\
\hline $\begin{array}{l}\text { US-Guatemala } \\
2002-2009\end{array}$ & 0.784 & 0.696 & $0.966^{* * *}$ \\
\hline $\begin{array}{l}\text { US-Honduras } \\
\text { 2002-2005 }\end{array}$ & 0.129 & -0.474 & $0.968^{* *}$ \\
\hline $\begin{array}{l}\text { US-Honduras } \\
2006-2009\end{array}$ & $0.971^{* *}$ & $0.952^{* *}$ & $0.966^{* *}$ \\
\hline $\begin{array}{l}\text { US-Honduras } \\
\text { 2002-2009 }\end{array}$ & 0.608 & $0.739^{*}$ & $0.932^{* * *}$ \\
\hline $\begin{array}{l}\text { Guatemala-El } \\
\text { Salvador 2002-2005 }\end{array}$ & 0.650 & 0.481 & 0.208 \\
\hline $\begin{array}{l}\text { Guatemala-El } \\
\text { Salvador 2006-2009 }\end{array}$ & 0.613 & 0.882 & 0.849 \\
\hline $\begin{array}{l}\text { Guatemala-El } \\
\text { Salvador 2002-2009 }\end{array}$ & 0.474 & 0.774 & 0.779 \\
\hline $\begin{array}{l}\text { Honduras-El } \\
\text { Salvador 2002-2005 }\end{array}$ & 0.857 & -0.092 & -0.875 \\
\hline $\begin{array}{l}\text { Honduras-El } \\
\text { Salvador 2006-2009 }\end{array}$ & $0.913^{*}$ & $0.934^{*}$ & $0.999^{* * *}$ \\
\hline
\end{tabular}




\begin{tabular}{|l|l|l|l|}
\hline $\begin{array}{l}\text { Honduras-El } \\
\text { Salvador 2002-2009 }\end{array}$ & $0.864^{* *}$ & $0.740^{*}$ & $0.901^{* * *}$ \\
\hline $\begin{array}{l}\text { Honduras- } \\
\text { Guatemala } \\
2002-2005\end{array}$ & $0.919^{*}$ & -0.275 & 0.279 \\
\hline $\begin{array}{l}\text { Honduras- } \\
\text { Guatemala } \\
2006-2009\end{array}$ & 0.791 & $0.933^{*}$ & 0.838 \\
\hline $\begin{array}{l}\text { Honduras- } \\
\text { Guatemala } \\
2002-2009\end{array}$ & 0.546 & $0.787^{*}$ & $0.738^{*}$ \\
\hline \begin{tabular}{l} 
Significance levels: ${ }^{*}=\mathrm{p}<0.1,{ }^{* *}=\mathrm{p}<0.05,{ }^{* * *}=\mathrm{p}<0.01$ \\
\hline
\end{tabular}
\end{tabular}

Considering exports, correlations are generally increasing in the post-CAFTA period between all states but only the US-Honduras and Honduras-El Salvador pairs were significant. After CAFTA-DR, there are generally higher correlations in industrial production and GDP growth with significant results for US-Honduras, US-Guatemala, and Honduras-El Salvador pairs. The significant correlation coefficients suggest increased co-movement as expected between the US and Guatemala and the US and Honduras but also between Honduras and El Salvador and Honduras and Guatemala in the post-CAFTA period. The latter is an interesting result and indicates some economic synchronization and integration between the developing states in the FTA in the postCAFTA period. This result falls in line with Molina, Bussolo, and Iacovone's findings that the Dominican Republic's exports to the US and other developing CAFTA-DR members have expanded since 2005, accelerated in 2007 before decreasing in 2009 (Molina, Iacovone, op. cit.). However, it must be noted that research on Central America synchronization before CAFTA-DR reported a small positive relationship between trade intensity and synchronization for CAFTA-DR states (Fiess 2007: 49-72). Synchronization was also found to be generally low compared to NAFTA but with the greatest comovement between Costa Rica, Guatemala, El Salvador and Honduras and between CAFTA-DR states and the US (World Bank Central America Department, 2005: 162-5). Then, controlling for the common impact of the U.S. business cycle, only Costa Rica and Guatemala, Costa Rica and El Salvador and Guatemala and Honduras are affected by common factors (Ibid.). These countries also account for the largest share of intraregional trade before CAFTA-DR (Ibid.). As a result, along with the short time period under consideration, the significant high correlations found in Table 3 can only suggest some preliminary indications of increasing business cycle convergence between developing CAFTA-DR states and between the US and CAFTA-DR states in the postCAFTA period.

24 To consider the symmetry of production structures for CAFTA-DR members, I again calculated sector output correlation coefficients. Table 4 below shows the Pearson's $r$ for the natural $\log$ of value added agriculture, the natural $\log$ of value added manufacturing, and the natural log of value added services sectors from annual World Bank data (World Bank op. cit.). Also to detrend the data, it was first differenced. I 
separated the results into equal time periods before and after the implementation of CAFTA, in this case 4 years and for the entire period between 2002-2009.

Table 4

Sector Correlation Coefficients

\begin{tabular}{|l|ll|ll|l}
\hline & Natural Log of Value & Natural Log of Value & Natural Log of Value \\
\hline
\end{tabular}

Added Agriculture Added Manufacturing Added Services

\begin{tabular}{|l|l|l|l|}
\hline $\begin{array}{l}\text { US-El Salvador } \\
2002-2005\end{array}$ & 0.502 & 0.085 & $0.969^{* *}$ \\
\hline US-El Salvador & & & (current US\$) \\
\hline
\end{tabular}

\begin{tabular}{|l|l|l|l|}
$\begin{array}{l}\text { US-El Salvador } \\
2006-2009\end{array}$ & -0.384 & 0.696 & 0.822 \\
\hline $\begin{array}{l}\text { US-El Salvador } \\
2002-2009\end{array}$ & -0.246 & 0.485 & 0.675 \\
\hline
\end{tabular}

\begin{tabular}{|l|l|l|l|}
\hline $\begin{array}{l}\text { US-Guatemala } \\
2002-2005\end{array}$ & $-0.988^{* *}$ & $0.971^{* *}$ & 0.208 \\
\hline $\begin{array}{l}\text { US-Guatemala } \\
2006-2009\end{array}$ & -0.751 & 0.669 & $0.930^{*}$ \\
\hline
\end{tabular}

\begin{tabular}{|l|l|l|l|}
$2006-2009$ & -0.751 & 0.669 & $0.930^{*}$ \\
\hline $\begin{array}{l}\text { US-Guatemala } \\
2002-2009\end{array}$ & -0.621 & 0.725 & 0.249 \\
\hline US-Honduras & -0.647 & 0.375 &
\end{tabular}

\begin{tabular}{|l|l|l|l|}
\hline $\begin{array}{l}\text { US-Honduras } \\
2002-2005\end{array}$ & -0.647 & 0.375 & $0.901^{*}$ \\
\hline $\begin{array}{l}\text { US-Honduras } \\
2006-2009\end{array}$ & -0.836 & 0.759 & 0.837 \\
\hline $\begin{array}{l}\text { US-Honduras } \\
\text { 2002-2009 }\end{array}$ & -0.701 & 0.584 & $0.771^{*}$ \\
\hline $\begin{array}{l}\text { Guatemala-El } \\
\text { Salvador } \\
\text { 2002-2005 }\end{array}$ & -0.584 & 0.037 & 0.073 \\
\hline $\begin{array}{l}\text { Guatemala-El } \\
\text { Salvador } \\
\text { 2006-2009 }\end{array}$ & 0.136 & $0.939^{*}$ & $0.943^{*}$ \\
\hline $\begin{array}{l}\text { Guatemala-El } \\
\text { Salvador } \\
\text { 2002-2009 }\end{array}$ & -0.134 & $0.827^{* *}$ & $0.740^{*}$ \\
\hline
\end{tabular}




\begin{tabular}{|c|c|c|c|}
\hline $\begin{array}{l}\text { Honduras-El } \\
\text { Salvador } \\
2002-2005\end{array}$ & -0.561 & -0.016 & $0.979^{* *}$ \\
\hline $\begin{array}{l}\text { Honduras-El } \\
\text { Salvador } \\
2006-2009\end{array}$ & 0.734 & 0.720 & 0.707 \\
\hline $\begin{array}{l}\text { Honduras-El } \\
\text { Salvador } \\
2002-2009\end{array}$ & 0.314 & 0.696 & 0.665 \\
\hline $\begin{array}{l}\text { Honduras- } \\
\text { Guatemala } \\
2002-2005\end{array}$ & 0.749 & 0.585 & 0.029 \\
\hline $\begin{array}{l}\text { Honduras- } \\
\text { Guatemala } \\
2006-2009\end{array}$ & 0.351 & 0.888 & 0.893 \\
\hline $\begin{array}{l}\text { Honduras- } \\
\text { Guatemala } \\
2002-2009\end{array}$ & 0.467 & $0.828^{* *}$ & 0.525 \\
\hline
\end{tabular}

In the agricultural sector, we see lower correlations in the CAFTA-DR period between high income-developing CAFTA-DR partners and higher correlations between developing CAFTA-DR members but most all of the correlation coefficients are not significant. While in the manufacturing sector, there are increasing correlations after the CAFTA-DR period for all pairs except for the US and Guatemala but again few results are significant. Lastly, there are no generalizable patterns in the service sector, with a majority of the coefficients not being significant. As we expect from the literature, overall weak correlations for most pairs in all sectors suggest asymmetrical production structures for all CAFTA-DR members. Indeed, prior research has found little evidence of IIT between developing CAFTA-DR members and the US, except for Coast Rica even before CAFTA-DR (Fiess op. cit.: 65). However, these post-CAFTA-DR sector correlations again only look at a very short-term period and must be expanded upon as more data become available.

After CAFTA-DR, there is some preliminary evidence based on output correlation coefficients to suggest greater macroeconomic synchronization of CAFTA-DR states in the post-CAFTA-DR period. However, these coefficients only consider the very shortterm after CAFTA-DR so they likely overestimate co-movement, especially since tariffs for non-agricultural products were already low prior to the implementation of CAFTADR and reductions in tariffs for agricultural products are gradual (Morley, 2005). In addition, asymmetrical production structures along with the lower level of income, smaller size, and less diversified production of developing members may weaken prospects for closer integration and synchronization between states. 


\section{Macroeconomic Synchronization, Volatility and Stability}

Macroeconomic volatility has been found to have a generally negative impact on GDP and output growth and it can have a negative effect on consumption growth, particularly in developing countries with limited access to international financial markets and weak domestic financial markets (Ramey, Ramey: 1138-51; Kose, Prasad, Terrones, 2003). In terms of output, macroeconomic volatility affects the level of uncertainty, which discourages investment and subsequently lowers output (Pindyck, 1991: 1110-1148). But for OECD countries, business cycle fluctuations have decreased since the mid-1980s (Dalsgaard, Elmeskov, Park 2002). According to Basu and Taylor, these changes in business cycle characteristics appear to be associated with changes over time in characteristics of the monetary system, particularly capital mobility or controls and fixed or floating exchange rate (Basu, Taylor 1999: 45-68). While there has been increasing capital mobility in international financial markets since the 1970s, as a result of deregulation and decreasing capital controls on foreign exchange, scholars have criticized the international financial institutions for pushing capital mobility on developing economies in the 1990s (Stiglitz 2003). Stiglitz in particular has largely attributed the currency crises in emerging market to the lack of capital controls for those states (Ibid.). To deal with macroeconomic volatility, consumption can be smoothed by borrowing, which is made possible with capital mobility. However, often developing countries are unable to do so due to the limited access to international financial markets, weak domestic financial markets, and poor regulation. So developing states are unable to benefit from capital mobility. Instead, large and sudden changes in capital flows will create macroeconomic volatility and even a currency crisis.

Consequently, it is no surprise that macroeconomic volatility occurs more frequently in developing countries than in high-income states (Loayza, Rancière, Servén, Ventura 2007). Developing and small sized countries with open economies can be more vulnerable to domestic and external shocks because they are unable to mitigate the effects of these kinds of economic disturbances ${ }^{12}$. This is due to four factors: 1) developing states are incapable of making fiscal policy adjustments to diversify risk; 2) they may not be able to shift sectors when economic conditions shift; 3 ) they have weak domestic financial markets; 4) they have fragile international financial links that restrict international borrowing (Callebero 2000: 31-88). Similarly, small economies, which are a characteristic of most CAFTA-DR members, have high trade shares and concentrated export structures that make them vulnerable to external shocks, which can further worsen macroeconomic volatility (Easterly, Kray 2000: 2013-2027). As a result, in these kinds of states, macroeconomic volatility can help precipitate financial crises, output loss, and reduced economic growth.

However, trade integration and greater macroeconomic synchronization with highincome industrial states may help reduce the cyclical fluctuations of developing member states in FTAs. This can result when increased trade leads to higher IIT in specialization and a larger volume of intermediate inputs trade, which can lower output volatility (Razin, Rose 1992: 48-76). Trade liberalization and higher business cycle symmetry also can secure market access, create a more stable investment climate, increase export diversification and reduce terms of trade risk from external terms of trade shocks (Lederman, Maloney, Servén op. cit.: 98-102); therefore, also decreasing 
the level of cyclical fluctuations and increasing macroeconomic stability for developing states. For example, research on NAFTA and the Peso Crisis suggests that instead of producing the crisis, NAFTA assisted in the swift conclusion of the crisis and helped make possible Mexico's increasing growth in the late 1990s, since NAFTA committed Mexico to open markets and prevented tariff increases (Burfisher, Robinson, Thierfelder, op. cit.: 133). NAFTA also gave Mexico guaranteed access to the U.S. market though the currency crisis, despite the growing competitiveness of Mexico's exports and the decreasing demand for imports (Ibid.). Finally, the formal obligations of both countries to NAFTA signaled their commitment and restored the confidence of investors about the future expectations for the economic recovery and growth of the Mexico (Ibid.).

In contrast, empirical research has also shown that developing states have more sensitivity to the economic developments and conditions of high-income partners in a FTA (International Monetary Fund, op. cit.:121-160). Trade integration can lead to increased output and consumption volatility when increased trade leads to higher inter-industry specialization in states and so these states are more likely to be sensitive to industry shocks (Krugman, 1993). As a result, the positive link between trade integration, greater synchronization, and stability works well when there are positive spillovers effects from high-income partner countries. Prior to the 2008 economic crisis, trade integration and synchronous effects can be seen as positive contributions to the financial stability of developing partner countries because spillovers were largely positive.

31 However, with emergence of the 2008 crisis in the United States, where spillover effects to partner countries have been negative, then trade integration and synchronization may not help produce increased stability and instead undermine stability. An early study of the effects of the 2008 crisis on NAFTA members found that economic integration has occurred under NAFTA but it has also made members more vulnerable to shocks, and if a crisis occurs in the United States, its spread is immediate to its NAFTA partners (Correa, Seccareccia, 2009). In addition, this study examined the Canadian banking sector and found that Canada had a strong national banking system, which can explain why Canada was more resilient in the face of the 2008 crisis than was the Mexican banking sector, which faced bankruptcy and nationalization (Ibid.). So in different contexts, the benefits of trade integration and business cycle synchronization may not outweigh the costs in terms of macroeconomic volatility and stability, even though the common perception views trade integration and business cycle synchronization as a positive contribution.

\subsection{Stability and Volatility after NAFTA}

Macroeconomic volatility, measured as the standard deviation of annual GDP growth rates, has decreased in Mexico since the implementation of NAFTA but it is still higher in Mexico than it is for the United States and Canada (Kose, Rebucci, op. cit.: 88). Macroeconomic volatility increased from the 1970s to the early 1980s with the debt crisis, and declined until 1994-1996 with the Tequila crisis (Lederman, Maloney, Servén op. cit.). Since 1996, GDP growth volatility has decreased but remains higher than levels in the 1970s (Ibid.). This reduction in GDP growth volatility could be a result of increasing vertical IIT from NAFTA but also better domestic macroeconomic policies, 
greater international financial access and common regional shocks (Kose, Meredith, Towe, op. cit: 17-18).

While there is a reduction in macroeconomic volatility after NAFTA, Swinston and Bayoumi find significant spillover effects from the US to Canada and Mexico (Swiston, Bayoumi, 2008). Specifically, they find that a 1 percent shock to US real GDP results in a shift of .75 percent in GDP in the same direction for Canada since 1989 and a 1.5 percent shift in the same direction for Mexico since 1996 (Ibid.). This means that GDP volatility while decreasing over the NAFTA period can still rise from negative spillover effects. However, states can decouple from the US economy with a flexible macroeconomic policy but this kind of flexibility will likely be easier for high-income states like Canada rather than a developing state like Mexico (International Monetary Fund op. cit.).

\subsection{Stability and Volatility after CAFTA-DR}

Overall, macroeconomic volatility has decreased since 1980-2003 for the members of CAFTA-DR (Kose, Rebucci op. cit: 88-89). This indicates that outside factors, beyond formal trade integration have played a great role in decreasing macroeconomic volatility, since CAFTA-DR went into effect after 2003 for member states. But looking to the NAFTA experience, GDP growth volatility may further decline for the developing CAFTA-DR states post-CAFTA as it did for Mexico after NAFTA, especially since consumption and investment volatility in CAFTA-DR countries were on the whole greater than Mexico in the same period (Ibid.: 89). Additionally, CAFTA could further lower economic volatility by contributing to the increased diversification of exports through access to the US market (Ibid.). However, more data will help clarify the role of CAFTA-DR in influencing macroeconomic volatility or stability.

Although macroeconomic volatility has diminished over time, a study on spillover effects from the US to CAFTA-DR states has found that a 1 percent shock to U.S. growth shifts economic activity by 0.7 to 1 percent in CAFTA-DR states, depending on the individual country (Swiston, Bayoumi op. cit.: 4). In comparison with the NAFTA states, these effects are just as significant for CAFTA-DR countries, especially since CAFTA-DR economies are much smaller than NAFTA states. In addition, shocks associated with the 2008 financial crisis were found to have lowered economic activity by about 4 to 5 percent for the CAFTA-DR states (Ibid.). Looking at spillover effects on specific CAFTA-DR countries, Costa Rica, Guatemala, and Honduras are more sensitive to external shocks so the responses to a US supply shock are generally deeper and more persistent for these states (Kose, Rebucci, op. cit.: 92-93). The Dominican Republic, El Salvador, and Nicaragua are more sensitive to domestic shocks so spillover effects in general have a smaller role (Ibid.). Therefore, CAFTA-DR, by increasing trade and financial integration may also contribute to significant spillover effects. As a result, the stabilizing effects of trade integration may be mitigated by negative spillover effects from the US, when the US's growth slows.

\section{Macroeconomic Synchronization and Policy Coordination}

The importance of financial spillovers, especially during the 2008 crisis, underscores the role policy coordination could play in stabilizing developing economies. But 
macroeconomic synchronization is important in determining the need for and benefits from policy coordination between countries. Policy coordination with high-income partners may benefit developing country partners by reducing macroeconomic volatility and increase stability, when macroeconomic variability is due to common shocks and not country-specific shocks. This is because developing countries would most likely benefit from coordinating with the stabilization policies of high-income countries, which are also facing similar shocks. So symmetrical financial and monetary policy adjustments may produce better results than asymmetrical adjustments, which may not provide enough stabilization. In contrast, idiosyncratic volatility driven by sector specific shocks would require monetary and fiscal policy autonomy to address country specific issues rather than policy coordination with another state. From Section 1 and 2, since we expect there to be less synchronization between developingindustrial pairs in a FTA because of asymmetric production structures and greater idiosyncratic macroeconomic volatility of a developing partner state, policy coordination is less appropriate for developing partner members. In high-income pairs, policy coordination is more advantageous because of greater business cycle synchronization and symmetric production structures.

Additionally from economic policy theory, the number of policy instruments must be at least as equal to the number of economic objectives if a state wants to achieve all those economic objectives (Tinbergen 1965). If the number of policy instruments is less that the number of target variables, then a state must sacrifice some of its economic objectives. This means that a state must have enough policy options to deal with various desired economic goals. However, as countries become more interdependent with increased trade integration, states find it increasingly difficult to pursue independent policy options because policy instruments like fixed exchange rates, tariff discrimination, and export subsidies are prohibited by free trade agreements (Cooper 1980). So increased trade integration and macroeconomic synchronization within FTAs may shrink the available options for states in dealing with economic shocks.

Moreover, from the Mundell-Fleming model, a state's policy options are further limited because it must choose between maintaining only two of the three following conditions: capital mobility, monetary policy autonomy, and a fixed exchange rate system. For example, a state can fix its exchange rate but only by maintaining capital controls, or a state can have free capital movement and retain independent monetary policy but only by allowing floating exchange rates, or a state can have free capital movement and stabilize their currency but then will be unable to adjust monetary policy to deal with inflation problems or with a recession. With the end of the Bretton Woods system and the Nixon shock, which resulted in floating exchanges rates for most states and increased exchange rate volatility, and the ease in which capital controls can be avoided now, states are left with even fewer policy instruments to choose from. However, with fewer choices and increased policy coordination with a high-income state, a developing state may benefit from increased international economic confidence due to greater domestic policy credibility as it would be now in a sense locked in with high-income partners. But policy coordination and its requisite loss of monetary policy autonomy has its costs, which must be weighed against its benefits. These costs are lower when there is business cycle synchronization between states and when states can use alternative policy instruments, like wage and price adjustments and labor flexibility to compensate for the loss of monetary policy autonomy. While this is likely 
the case for high-income states, this is not likely the case for developing countries. As a result, we should expect little policy coordination between developing and highincome state members of a FTA and more policy coordination between industrialized pairs within a FTA.

\subsection{Policy Coordination after NAFTA}

Policy coordination requires a set of formal and informal common policies. However, since NAFTA establishes a FTA and does not require the formal adoption of policy rules, I measure policy coordination with correlation coefficients between key monetary and financial policy indicators from annual World Bank data (World Bank op. cit.). Monetary indicators are money and quasi- money growth, the natural log of total reserves, and inflation. Fiscal indicators are current account balance, foreign direct investment inflows, and government consumption. Table 5 reports the Pearson's $r$ for all policy indicators. There is increasing positive movement of correlations in the postNAFTA period for all member states but only measures of FDI, inflation, and reserves show significant correlations between the US-Canada pair. Overall for most indicators, there is little indication of policy coordination between NAFTA members.

Table 5

\begin{tabular}{|c|c|c|c|}
\hline \multicolumn{4}{|c|}{ Policy Indicator Correlation Coefficients } \\
\hline Fiscal Variables & $\begin{array}{l}\text { Current account } \\
\text { balance (\% of GDP) }\end{array}$ & $\begin{array}{lr}\text { Foreign } & \text { Direct } \\
\text { Investment, Net } & \text { inflows } \\
(\% G D P) & \end{array}$ & $\begin{array}{l}\text { Government final consumption } \\
\text { expenditure (annual \% growth) }\end{array}$ \\
\hline $\begin{array}{l}\text { US-Mexico } \\
1980-1993\end{array}$ & -0.408 & -0.304 & -0.511 \\
\hline $\begin{array}{l}\text { US-Mexico } \\
1994-2007\end{array}$ & 0.238 & -0.186 & -0.139 \\
\hline $\begin{array}{l}\text { US-Mexico } \\
1980-2007\end{array}$ & -0.224 & -0.200 & $-0.337^{*}$ \\
\hline $\begin{array}{l}\text { Canada-Mexico } \\
1980-1993\end{array}$ & 0.140 & $-0.538^{*}$ & -0.160 \\
\hline $\begin{array}{l}\text { Canada-Mexico } \\
\text { 1994-2007 }\end{array}$ & 0.272 & -0.148 & -0.331 \\
\hline $\begin{array}{l}\text { Canada-Mexico } \\
1980-2007\end{array}$ & 0.192 & -0.173 & -0.224 \\
\hline $\begin{array}{l}\text { US-Canada } \\
1980-1993\end{array}$ & -0.079 & 0.311 & 0.401 \\
\hline $\begin{array}{l}\text { US-Canada } \\
\text { 1994-2007 }\end{array}$ & -0.401 & $0.523^{*}$ & -0.003 \\
\hline
\end{tabular}




\begin{tabular}{|c|c|c|c|}
\hline $\begin{array}{l}\text { US-Canada } \\
1980-2007\end{array}$ & -0.201 & $0.494^{* *}$ & 0.255 \\
\hline $\begin{array}{l}\text { Monetary } \\
\text { Variables }\end{array}$ & $\begin{array}{l}\text { Inflation, GDP } \\
\text { deflator (annual \%) }\end{array}$ & $\begin{array}{l}\text { Money and quasi money } \\
\text { growth (annual \%) }\end{array}$ & $\begin{array}{l}\text { Natural Log Total reserves, } \\
\text { including gold (current US\$) }\end{array}$ \\
\hline $\begin{array}{l}\text { US-Mexico } \\
1980-1993\end{array}$ & -0.311 & -0.345 & -0.199 \\
\hline $\begin{array}{l}\text { US-Mexico } \\
\text { 1994-2007 }\end{array}$ & -0.039 & 0.160 & 0.055 \\
\hline $\begin{array}{l}\text { US-Mexico } \\
1980-2007\end{array}$ & -0.267 & -0.211 & -0.105 \\
\hline $\begin{array}{l}\text { Canada-Mexico } \\
1980-1993\end{array}$ & 0.003 & -0.024 & -0.212 \\
\hline $\begin{array}{l}\text { Canada-Mexico } \\
1994-2007\end{array}$ & 0.404 & 0.397 & 0.167 \\
\hline $\begin{array}{l}\text { Canada-Mexico } \\
1980-2007\end{array}$ & 0.087 & 0.107 & -0.050 \\
\hline $\begin{array}{l}\text { US-Canada } \\
1980-1993\end{array}$ & $0.736^{* * *}$ & 0.356 & $0.594^{* *}$ \\
\hline $\begin{array}{l}\text { US-Canada } \\
1994-2007\end{array}$ & $0.531^{*}$ & 0.164 & 0.167 \\
\hline $\begin{array}{l}\text { US-Canada } \\
1980-2007\end{array}$ & $0.623^{* * *}$ & 0.143 & $0.470^{* *}$ \\
\hline
\end{tabular}

The lack of policy coordination is not surprising because idiosyncratic shocks are important, especially for Mexico. The costs of losing monetary policy autonomy are high when there are negative spillovers from the US. Common policies would not offer enough stabilization for Mexico if there were an asymmetric shock from a financial crisis. This is due to several factors: 1) counter cyclical policies like wage and price flexibility are harder for Mexico to achieve; 2) fiscal policy adjustments will be needed in these kinds of situations; 3) Mexico has weaker links to international finance sources and weaker domestic credit markets than the US and Canada (Lederman, Maloney, Servén, op. cit: 105-110). Additionally, while the US may follow similar policies facing external shocks, the intensity of policies would not be the same for Mexico or Canada, given the magnitude of spillover effects. Therefore, policy autonomy is still necessary even with increased trade integration among NAFTA members since states now also face fewer available policy options. Indeed, Correa and Seccareccia's research on the 2008 crisis and NAFTA found that financial and trade openness, NAFTA commitments, and a balanced budget law constrained the ability of the Mexican government to 
address the economic crisis with an appropriate countercyclical program (Correa, Seccareccia op. cit.: 95).

\subsection{Policy Coordination after CAFTA-DR}

41 Similar to the NAFTA section, I measure policy coordination with correlation coefficients between key monetary and financial policy indicators between two member countries from annual WB data (World Bank op. cit.). I chose El Salvador and Guatemala again because they are early members of CAFTA-DR and they also had the most data available for the 2002-2009 period. Monetary indicators are money and quasi- money growth, the natural log of total reserves, and inflation. Fiscal indicators are current account balance, foreign direct investment inflows, and government consumption. Table 6 shows the Pearson's $r$ for all the indicators. Again in general, for most indicators, we see very little policy coordination between CAFTA-DR members. For the period from 2006-2009, the correlations may be misleading because there are only observations for 4 years and they encompass the period of the financial crisis.

Table 6

\begin{tabular}{|c|c|c|c|}
\hline \multicolumn{4}{|c|}{ Policy Indicator Correlation Coefficients } \\
\hline Fiscal Variables & $\begin{array}{l}\text { Current account } \\
\text { balance (\% of GDP) }\end{array}$ & $\begin{array}{l}\text { Foreign Direct } \\
\text { Investment, Net inflows } \\
\text { (\%GDP) }\end{array}$ & $\begin{array}{l}\text { Government final consumption } \\
\text { expenditure (annual \% growth) }\end{array}$ \\
\hline $\begin{array}{l}\text { US-El Salvador } \\
2002-2005\end{array}$ & $-0.972^{*}$ & 0.093 & -0.679 \\
\hline $\begin{array}{l}\text { US-El Salvador } \\
2006-2009\end{array}$ & 0.756 & -0.023 & 0.713 \\
\hline $\begin{array}{l}\text { US-El Salvador } \\
2002-2009\end{array}$ & 0.551 & -0.011 & 0.206 \\
\hline $\begin{array}{l}\text { US-Guatemala } \\
2002-2005\end{array}$ & -0.669 & 0.745 & -0.371 \\
\hline $\begin{array}{l}\text { US-Guatemala } \\
\text { 2006-2009 }\end{array}$ & 0.881 & 0.580 & 0.159 \\
\hline $\begin{array}{l}\text { US-Guatemala } \\
2002-2009\end{array}$ & 0.708 & 0.502 & -0.011 \\
\hline $\begin{array}{l}\text { El Salvador- } \\
\text { Guatemala } \\
2002-2005\end{array}$ & $-0.912^{*}$ & -0.176 & 0.421 \\
\hline $\begin{array}{l}\text { El Salvador- } \\
\text { Guatemala } \\
2006-2009\end{array}$ & $0.915^{* *}$ & 0.763 & 0.316 \\
\hline
\end{tabular}




\begin{tabular}{|c|c|c|c|}
\hline $\begin{array}{l}\text { El Salvador- } \\
\text { Guatemala } \\
2002-2009\end{array}$ & $0.745^{*}$ & $0.083^{* *}$ & 0.266 \\
\hline $\begin{array}{l}\text { Monetary } \\
\text { Variables }\end{array}$ & $\begin{array}{l}\text { Inflation, } \quad \text { GDP } \\
\text { deflator } \\
\% \text { (annual }\end{array}$ & $\begin{array}{l}\text { Money and quasi money } \\
\text { growth (annual \%) }\end{array}$ & $\begin{array}{l}\text { Natural Log Total reserves, } \\
\text { including gold (current US\$) }\end{array}$ \\
\hline $\begin{array}{l}\text { US-El Salvador } \\
2002-2005\end{array}$ & 0.879 & 0.874 & 0.319 \\
\hline $\begin{array}{l}\text { US-El Salvador } \\
2006-2009\end{array}$ & 0.394 & 0.313 & 0.373 \\
\hline $\begin{array}{l}\text { US-El Salvador } \\
2002-2009\end{array}$ & 0.591 & 0.385 & 0.493 \\
\hline $\begin{array}{l}\text { US-Guatemala } \\
\text { 2002-2005 }\end{array}$ & $-0.929 *$ & 0.084 & -0.155 \\
\hline $\begin{array}{l}\text { US-Guatemala } \\
2006-2009\end{array}$ & 0.460 & -0.414 & 0.587 \\
\hline $\begin{array}{l}\text { US-Guatemala } \\
\text { 2002-2009 }\end{array}$ & 0.026 & 0.003 & -0.148 \\
\hline $\begin{array}{l}\text { El Salvador- } \\
\text { Guatemala } \\
2002-2005\end{array}$ & $-0.982^{* *}$ & 0.539 & 0.697 \\
\hline $\begin{array}{l}\text { El Salvador- } \\
\text { Guatemala } \\
2006-2009\end{array}$ & $0.948^{*}$ & 0.200 & 0.352 \\
\hline $\begin{array}{l}\text { El Salvador- } \\
\text { Guatemala } \\
2002-2009\end{array}$ & 0.284 & 0.414 & 0.350 \\
\hline
\end{tabular}

Once more we see a general lack of policy coordination between the US and developing CAFTA-DR members surveyed here. However, the CAFTA-DR members do have high levels of trade with the US and have strong ties to the US dollar, which indicates that there may be some benefits to policy coordination. For example, El Salvador presents an interesting case because since 2001 it has dollarized and uses the US dollar as its currency. Dollarization tends to reduce policy autonomy for states and signifies that a state cannot undertake its own monetary policy. Nonetheless, the correlation coefficients for the monetary policy variables were increasing but not significant for the US- El Salvador pair. In addition, CAFTA-DR states that are sensitive to domestic shocks also face the same problems as Mexico. So those CAFTA-DR members will generally need to keep high policy autonomy to address country-specific conditions. 


\section{Conclusion}

This article has sought to answer two key questions: (1) to what degree is there macroeconomic synchronization and policy coordination between member countries of NAFTA and CAFTA-DR? and (2) what are the effects of increasing macroeconomic synchronization on the macroeconomic policy for NAFTA and CAFTA-DR partner countries? While full economic convergence is not occurring after NAFTA, there is some macroeconomic synchronization in the post-NAFTA period, which has consequences for the appropriateness of policy coordination. There is also some preliminary evidence that CAFTA-DR economies also show some convergence. Looking at the role of trade integration on volatility, overall macroeconomic volatility has decreased for NAFTA and CAFTA-DR members after implementation. However, the US as a key partner produces both negative and positive spillover effect to other member states. This means synchronization can be costly for developing NAFTA and CAFTA-DR states, and domestic policy remedies are still required. Finally, I find that there is little policy coordination under NAFTA and CAFTA-DR, which can be understood by the logic that the loss of policy autonomy still outweighs the benefits of coordination for most developing state members. However, given the amount of time that has passed since the implementation of NAFTA and even more briefly for CAFTA-DR, my findings must be examined with future data about patterns of trade and changes in policy.

\section{BIBLIOGRAPHIE}

Aggarwal, Raj and NyoNyo A. Kyaw, "Equity market integration in the NAFTA region: Evidence from unit root and cointegration tests", International Review of Financial Analysis, vol. 14, 2005, pp. 393-406.

Artis, Michael and Wenda Zhang, "International Business Cycles and the ERM: Is there a European Business Cycle?”, Centre for Economic Policy Research Discussion Paper, no ${ }^{\circ}$ 1191, 1995.

Angeloni I. and L. Dedola, "From the ERM to the Euro: New Evidence on Economic and Policy Convergence Among EU Countries”, European Central Bank Working Paper, no 4, 1999.

Basu, Susanto and Alan M. Taylor, "Business Cycles in International Historical Perspective", The Journal of Economic Perspectives, vol. 13, n², 1999, pp. 45-68.

Belo, Frederico, "Some Facts About the Cyclical Convergence in the Euro Zone" Bank of Portugal Working Paper, 2001.

Blecker, Robert A., "The North American Economies After NAFTA: A Critical Appraisal”, International Journal of Political Economy, vol. 33, n 3, 2003, pp. 5-27.

Boone, Laurence, "Symmetry and Asymmetry of Supply and Demand Shocks in the European Union: A Dynamic Analysis", Centre d'Études Prospectives et d'Information Internationale Working Paper, nº 97-03, 1997. 
Böwer, Uwe and Catherine Guillemineau, "Determinants of Business Cycle Synchronisation Across Euro Area Countries”, European Central Bank Working Paper Series, nํ587, 2006.

Brulhart, Marius and Michael Thorpe, "Export Growth of NAFTA Members, Intraindustry Trade and Adjustment", Global Business and Economics Review, vol. 3, nº 1, 2001, pp. 94-110.

Burfisher, Mary E., Sherman Robinson and Karen Thierfelder, "The Impact of NAFTA on the United States”, Journal of Economic Perspectives, vol. 15, n 1, 2001, pp. 125-144.

Calderon, Cesar, Alberto Chong, and Ernesto Stein, "Trade Intensity and Business Cycle Synchronization: Are Developing Countries any Different?", Journal of International Economics, vol. $71, \mathrm{n}^{\mathrm{o}}$ 1, 2007, pp. 2-21.

Callebero, Ricardo J., "Macroeconomic Volatility in Latin America: A Conceptual Framework and Three Case Studies”, Economia, vol. 1, no 1, 2000, pp. 31-88.

Caves, Richard, "Intra-Industry Trade and Markets Structures in the Industrial Countries", Oxford Economic Papers New Series, vol. 33, no 2, 1981, pp. 203-223.

Chukwuogor-Ndu, Chiaku and Krishna Kasibhatla, "Post NAFTA Integration of North American Stock Markets: Implications for Financial Decision Making", North American Journal of Finance and Banking, vol. 1, nº 1, 2007, pp. 37-53.

Clark, Don, "Intra-Industry Specialization in United States-Mexico Trade", Global Economy Journal, vol. 10, no 2, 2010, p. 1-16.

Congressional Budget Office, "The Effects of NAFTA on U.S.-Mexican Trade and GDP”, CBO Paper, 2003.

Cooper, Richard, The Economics of Interdependence, New York, Columbia University Press, 1980.

Correa, Eugenia and Mario Seccareccia, "The United States Financial Crisis and Its NAFTA Linkages”, International Journal of Political Economy, vol. 38, ํㅡ 2, Summer 2009, pp. 70-99.

Cuevas, Alfredo, Miguel Messmacher, and Alejandro Werner, "Macroeconomic Synchronization between Mexico and its NAFTA Partners”, Banco de Mexico Working Paper, no 2003-01.

Dalsgaard, T., J. Elmeskov and C-Y. Park, "Ongoing Changes in the Business Cycle: Evidence and Causes", OECD Economics Department Working Paper, n³15, 2002.

Easterly, William and Aart Kray, "Small States, Small Problems? Income, Growth, and Volatility in Small States", World Development, vol. 28, 2000, pp. 2013-2027.

Ekanayake, E.M., Bala Veeramacheneni and Carlos Moslares, "Vertical and Horizontal Intraindustry trade Between the U.S. and NAFTA Partners”, Revista de Análisis Económico, vol. 24, oㅡㄴ pp. 21-42.

Feils, Dorothee J. and Manzur Rahman, "Regional economic integration and foreign direct investment: The case of NAFTA”, Contemporary Economic Policy, vol. 48, no 2, 2008, pp. 147-163.

Fidrmuc, Jarko, "The Endogeneity of the Optimum Currency Area Criteria, Intra-Industry Trade, and EMU Enlargement", Contemporary Economic Policy, vol. 22, nº 1, 2004, pp. 1-12.

Fiess, Norbert, "Business Cycle Synchronization and Regional Integration: A Case Study for Central America”, The World Bank Economic Review, vol. 21, n¹, 2007, pp. 49-72.

Fonseca, Raquel, Lise Patureau, and Thepthida Sopraseuth, "Business Cycle Comovement and Labor Market Institutions: An Empirical Investigation”, Review of International Economics, vol. 18, no 5, 2010, pp. 865-881. 
Fontagné, Lionel, Michel Freudenberg, Guillaume Gaulier, "Disentangling Horizontal and Vertical Intra-Industry trade", Centre d'Études Prospectives et d'information Internationale Working Paper, no 2005-10, pp. 31-88.

Frankel, Jeffrey A. and Andrew K. Rose, "The Endogeneity of the Optimum Currency Area Criteria", Economic Journal, vol. 108, nº 449, 1998, pp. 1009-1025.

Fuchs, Victor R., The Service Economy, New York, Columbia University Press for the National Bureau of Economic Research, 1968.

Gilmore, Claire G. and Ginette M. McManus, "The Impact of NAFTA on the Integration of Canadian, Mexican, and U.S. Equity Markets", in North American economic and financial integration, ed. Alan M. Rugman, Oxford, Elsevier Ltd, 2004, pp. 137-150.

Grubel, Herbert G. and P.J. Lloyd, Intra-Industry Trade: The Theory and Measurement of International Trade in Differentiated Products, London, Macmillan, 1975.

Havrylyshyn, Oli and Engin Civan, "Intra-industry trade among developing countries", Journal of Development Economics, vol. 18, no 2-3, 1985, pp. 253-271.

Hornbeck, J.F., “U.S.-Latin America Trade: Recent Trends and Policy Issues”, Congressional Research Service Report, 2010.

Hornbeck, J.F., “U.S.-Latin America Trade: Recent Trends and Policy Issues”, Congressional Research Service Report, 2009.

Hornbeck, J.F., “U.S.-Latin America Trade: Recent Trends and Policy Issues”, Congressional Research Service Report, 2008a.

Hornbeck, J.F., “U.S.-Latin America Trade: Recent Trends and Policy Issues”, Congressional Research Service Report, $2008 \mathrm{~b}$.

Hufbauer, Gary Clyde and Jeffrey J. Schott, NAFTA Revisited: Achievements and Challenges, Washington D.C.,The Institute for International Economics, 2005.

Imbs, Jean, "Trade, Finance, Specialization, and Synchronization", Review of Economics and Statistics, vol. 86, nº 3, 2004, pp. 723-734.

Inklaar, Robert, Richard Jong-A-Pin, and Jakob de Haan, "Trade and Business Cycle Synchronization in OECD Countries: A Re-examination”, CESifo Working Paper, 끌 1546, 2005.

International Monetary Fund, “World Economic Outlook: The International Technology Revolution”, International Monetary Fund Occasional Paper, ํㅡㄹ 2, 2001.

International Monetary Fund, "World Economic Outlook: Spillovers and Cycles in the Global Economy”, International Monetary Fund Occasional Paper, nํㅜ 1, 2007.

Kose, M. Ayhan, Guy Meredith, and Christopher Towe, "How Has NAFTA Affected the Mexican Economy? Review and Evidence”, IMF Working Paper nº WP/04/59, 2004.

Kose, M. Ayhan, Eswar S. Prasad, and Marco E. Terrones, "Financial Integration and Macroeconomic Volatility”, IMF Staff Papers, vol. 50, Special Issue, 2003.

Kose, M. Ayhan and Alessandro Rebucci, "How might CAFTA-DR change macroeconomic fluctuations in Central America? Lessons from NAFTA", Journal of Asian Economics, vol. 16, 2005, pp. 77-104.

Kreinin, Mordechai E. and Michael G. Plummer, "Effects of regional integration on FDI: An empirical approach", Journal of Asian Economics, vol. 19, 2008, pp. 497-454. 
Krugman, Paul, “Intraindustry Specialization and the Gains from Trade”, Journal of Political Economy, vol. 89, nº 5, 1981, pp. 959-973.

Krugman, Paul, "Lessons of Massachusetts for EMU”, in The Transition to Economic and Monetary Union in Europe, eds. F. Giavazzi and F. Torres. New York, Cambridge University Press, 1993.

Lederman, Daniel, William F. Maloney, and Luis Servén, Lessons from NAFTA: For Latin America and the Caribbean, Palo Alto: Stanford Economics and Finance, 2005.

Loayza, Norman, Romain Rancière, Luis Servén, and Jaume Ventura, "Macroeconomic Volatility and Welfare in Developing Countries", World Bank Economic Review, vol. 21, no 3, 2007.

Michela, Martinoia, "European integration, labour market dynamics and migration flows", POLIS Working Papers, ㄲo136, 2009.

Mckinnon, Ronald, “Optimum Currency Areas”, The American Economic Review, vol. 53, 1963, pp. 717-724.

Molina, Ana Cristina, Maurizio Bussolo, and Leonardo Iacovone, "The DR-CAFTA and the extensive margin: A firm-level analysis", World Bank Policy Research Working Paper, no 5340, 2010.

Morley, Samuel, "Trade Liberalization under CAFTA: An Analysis of the Agreement with special reference to agriculture and smallholders in Central America", International Food Policy Research Institute DSGD Discussion Paper, $\mathrm{n}^{\circ}$ 33/ International Food Policy Research Institute MTID Discussion Paper, $n^{\circ}$ 95, 2005.

Mundell, Robert A., “A Theory of Optimum Currency Areas”, The American Economic Review, vol. 51, no 4, 1961, pp. 657-665.

Pindyck, Robert S., "Irreversibility, Uncertainty, and Investment”, Journal of Economic Literature, vol. 29, 1991, pp. 1110-1148.

Qasmi, Bashir A. and Scott W. Fausti, "NAFTA Intra-industry Trade in Agricultural Food Products", Agribusiness, vol. 17, no 2, 2001, pp. 255-271.

Ramey, Garey and Valerie A. Ramey, "Cross Country Evidence on the link between Volatility and Growth”, American Economic Review, vol. 85, 1995, pp. 1138-51.

Ramos, R., M. Clarr, and J. Suriñat, "National versus Sectoral Shocks: New Evidence for the Manufacturing Sector in European Countries”, Economics Letters, vol. 78, 2003, pp. 241-245.

Razin, Assaf and Andrew Rose, "Business Cycle Volatility and Openness: An Exploratory Cross Sectional Analysis", in Capital Mobility: The Impact on Consumption, Investment, and Growth, eds. Lenardo Leiderman and Assaf Razin, Cambridge University Press, 1992, pp. 48-76.

Robertson, Raymond, "Has NAFTA Increased Labor Market Integration between the United States and Mexico?", World Bank Economic Review, vol. 19, nº 3, 2005, pp. 425-448.

Shelburne, Robert C., "Trade Liberalization and Intra-Industry Trade: The Case of the United States and Mexico", Global Economy Quarterly, vol. 2, no 3, 2001, pp. 215-234.

Stiglitz, Joseph, Globalization and Its Discontents, New York, W.W. Norton, 2003.

Swiston, Andrew, "Spillovers to Central America in Light of the Crisis: What a Difference a Year Makes”, IMF Working Paper, no WP/10/35, 2010.

Swiston, Andrew and Tamom Bayoumi, "Spillovers Across NAFTA", IMF Working Paper, n⿳o WP/ 08/3, 2008. 
Tinbergen, Jan, Economic Policy: Theory and Design, Amsterdam, The Netherlands, North Holland Publishing Co, 1965.

Torres, Alberto and Oscar Vela, "Trade integration and synchronization between the business cycles of Mexico and the United States", The North American Journal of Economics and Finance, vol. 14, no 3, 2003, pp. 319-342.

Villarreal, M. Angeles, "Industry Trade Effects Related to NAFTA", Congressional Research Service Report, 2003.

World Bank, World Bank Development Indicators and Global Development Finance 2011. http:// data.worldbank.org/. Accessed June 3, 2011.

World Bank Central America Department and Office of the Chief Economist Latin America and Caribbean Region, "DR-CAFTA: challenges and opportunities for Central America", World Bank Working Paper, n 32953, 2005.

Worth, Thomas, "Regional Trade Agreements and Foreign Direct Investment", U.S. Department of Agriculture Agricultural Economic Report, nº 772, 1998, pp. 76-86.

\section{NOTES}

1. This relationship follows from optimum currency area theory. See Mundell 1961: 657-665 and Mckinnon 1963: 717-724.

2. See Artis, Zhang 1995; Angeloni, Dedola 1999; Belo 2001; Boone 1997; Ramos, Clarr, Suriñat 2003: 241-245.

3. Generally, asymmetrical production structures between countries indicate higher specialization and more inter-industry trade. Similar production structures between countries indicate less specialization and more intra-industry trade.

4. I use the World Bank (WB) classification scheme. The WB classifies countries according to gross national income per capita, into the categories of low income, lower middle income, upper middle income, and high income. The term developing countries corresponds to the low income plus the middle income categories. See World Bank, 2011, "How we Classify Countries", <http:// data.worldbank.org/about/country-classifications>. Accessed June 3, 2011.

5. There was a supplemental agreement, the North American Agreement on Labor Cooperation that called for the enforcement of domestic labor laws.

6. In addition, prior to NAFTA, the US-Canada Fress Trade Agreement had been in force since 1989 and so US-Canada industries were already integrated before 1994.

7. Of the different measures of correlation, here I specifically calculate Pearson's product moment correlation coefficients (Pearson's $r$ ), which are defined as the covariance of the two variables divided by the product of their standard deviations, giving a value between +1 and -1 with values near 0 indicating little to no correlation and values near +1 and -1 signifying strong correlation. This covariance quantifies how one variable changes as the other variable changes and so it also illustrates the strength of the association between the two variables. I also use Pearson's $r$ since it is a symmetric measure meaning that it does not distinguish between an independent and a dependent variable. Lagged effects models, which are commonly utilized, would be more approporiate when dependent and independent variables are required. Moreover, Pearson's $r$ only detects the linear dependence between two variables, which suits the data used in this study. The linearity of data used in this study was checked graphically through bivariate scatter plots. Thus, Pearson's $r$ can be used to look at how closely states' outputs vary with each other, indicating synchronization between them. 
8. This can also be attributed to the strength of the US economy and relative wages in Mexico in addition to NAFTA. See M. Angeles Villarreal, "Industry Trade Effects Related to NAFTA", op. cit. 9. Date in parentheses indicates the date the agreement went into effect for the country.

10. Nicaragua had too much missing data to include in this analysis even though Nicaragua joined in 2006 as well.

11. I again used three measures of output: the natural log of exports of goods and services, the natural log of value added industrial output, and GDP growth. Furthermore to detrend the data, it was first differenced. I separated the results into equal time periods before and after the implementation of CAFTA, in this case 4 years and for the entire period between 2002-2009.

12. External shocks like terms of trade shocks are especially important if external trade is concentrated in commodities.

\section{RÉSUMÉS}

Malgré d'importantes et nombreuses disparités, au sein de l'Accord de libre-échange nordaméricain (ALENA), entre les pays à hauts revenus et les pays en voie de développement, la synchronisation des cycles d'affaires a succédé à une intégration commerciale accrue depuis la création de l'ALENA. Les économies de certains Etats membres de l'Accord de libre-échange entre l'Amérique centrale, les Etats-Unis et la République Dominicaine (l'ALEAC-RD) donnent également des signes attestant une convergence de leurs cycles d'affaires, bien qu'il soit encore trop tôt pour en tirer des conclusions significatives, étant donné le peu de recul dont nous disposons. La synchronisation macroéconomique revêt une importance particulière pour décider des politiques à adopter, car elle révèle les besoins et avantages de la coordination de ces politiques. Cette coordination avec les pays membres à hauts revenus pourrait s'avérer profitable aux pays membres en voie de développement, en réduisant la volatilité macroéconomique et en accroissant la stabilité, puisque la variabilité macroéconomique résulte de chocs communs et non de chocs spécifiques à un pays. La volatilité idiosyncrasique nécessiterait l'autonomie des politiques monétaires et fiscales plutôt que leur coordination. Alors même que l'intégration commerciale réduit les options des Etats membres en matière de politiques à adopter, les inconvénients d'une perte d'autonomie en ce domaine pèseraient bien davantage, pour les pays en voie de développement membres de l'ALENA et de l'ALEAC-RD, que les bénéfices d'une coordination, étant donnée la variabilité macroéconomique et idiosyncrasique de ces pays.

In spite of many significant differences between high-income and developing country partners in the North American Free Trade Agreement (NAFTA), business cycle synchronization has followed increased trade integration in the post-NAFTA period. There is also some preliminary support for some convergence between Dominican Republic-Central American Free Trade Agreement (CAFTA-DR) economies post-CAFTA-DR, although it is too soon to reach any significant conclusions. Macroeconomic synchronization has important implications for policy making because it indicates the need for and benefits from policy coordination. Policy coordination with high-income partners may benefit developing country partners by reducing macroeconomic volatility and increase stability, when macroeconomic variability is due to common shocks and not country-specific shocks. Idiosyncratic volatility would require monetary and fiscal policy autonomy rather than coordination. Examining policy coordination between NAFTA states and between CAFTA-DR members, I find little evidence for policy coordination before and after 
implementation of the FTA. For the developing partners in NAFTA and CAFTA-DR, even as trade integration shrinks the available policy options for member states, the costs of losing policy autonomy largely outweigh the benefits of coordination because of the idiosyncratic macroeconomic variability of the developing partners.

A pesar de las numerosas diferencias significativas que existen entre los países de renta alta y los países en desarrollo miembros del Tratado de Libre Comercio de América del Norte (TLCAN), la sincronización de los ciclos económicos ha seguido a una integración comercial en aumento desde la entrada en vigor del TLCAN. Asimismo, existen pruebas de que algunas economías del CAFTA-DR (Tratado de Libre Comercio entre República Dominicana, Centroamérica y Estados Unidos) muestran también una cierta convergencia de los ciclos económicos pese a que es demasiado pronto para llegar a conclusiones relevantes en un periodo tan corto de tiempo. La sincronización macroeconómica es importante para la toma de decisiones, dado que expresa la necesidad de coordinar políticas y muestra las ventajas de dicha coordinación. La coordinación de políticas con los socios con rentas elevadas puede beneficiar a los países en desarrollo gracias a la reducción de la volatilidad macroeconómica y al aumento de la estabilidad cuando la variabilidad macroeconómica se debe a perturbaciones comunes y no a desajustes específicos de un país. La volatilidad idiosincrática requeriría la autonomía de la política monetaria y fiscal más que una coordinación. Para los países socios en desarrollo del TLCAN y el CAFTA-DR, pese a que la que integración comercial reduce las distintas posibilidades de actuación política de los Estados miembros, el coste que representa la pérdida de autonomía supera con creces los beneficios de la coordinación a causa de la variabilidad macroeconómica idiosincrática de los países socios en desarrollo.

INDEX

Keywords : NAFTA, CAFTA, policy coordination, macroeconomic synchronization, regional integration, economic volatility

Mots-clés : ALENA, ALEAC, coordination politique, synchronisation macroéconomique, intégration régionale, volatilité économique

Palabras claves : TLCAN, CAFTA, coordinación política, sincronización macroeconómica, integración regional, volatilidad económica

\section{AUTEUR}

HELEN CHANG

hchang1@gc.cuny.edu

City University of New York, Graduate Center 